\title{
PERAN PEREMPUAN PENJUAL IKAN KELILING DALAM MENINGKATKAN PENDAPATAN KELUARGA DI KELURAHAN TUMUMPA DUA KECAMATAN TUMINTING KOTA MANADO
}

\author{
Polaria Maradou'; Djuwita R.R. Aling'; Florence V. Londong ${ }^{2}$ \\ 1) Mahasiswa Fakultas Perikanan dan IImu Kelautan Universitas Sam Ratulangi, Manado. \\ 2) Staff Pengajar Fakultas Perikanan dan IImu Kelautan Universitas Sam Ratulangi, Manado. \\ Koresponden email: maradoupolaria92@gmail.com
}

\begin{abstract}
Women's involvement in economic activities should be recognized, although in reality there are differences between men and women in work activities. Working women can help the husband in supporting the family economy, the role of working women is needed especially in terms of helping to increase family income. Factors affecting women's involvement in the labor market are: external factors, internal factors, employment factors and economic needs fulfillment factors that enable women to work in the public sector.

The research objectives are: 1) To know the general condition of women selling fish in Tumumpa Dua Village, Tuminting Sub-district, Manado City, and 2) To describe how the role of women selling fish in increasing income. The research method used descriptive method with the base of case study research with data retrieval method using purposive sampling method.

The results showed that the role of women in the family fish seller is very important. Although the time spent on selling fish is only 2 hours - 3 hours but it is very influential in increasing family income.
\end{abstract}

Keywords: Roles, women selling fish, income

\begin{abstract}
Abstrak
Keterlibatan perempuan dalam kegiatan ekonomi harus diakui, walaupun pada kenyataanya ada perbedaan antara laki-laki dan perempuan dalam kegiatan kerja. Perempuan yang bekerja dapat membantu suami dalam mendukung perekonomian keluarga, peran perempuan yang bekerja sangat dibutuhkan terutama dalam hal membantu menambah penghasilan keluarga. Faktor yang mempengaruhi keterlibatan perempuan dalam pasar tenaga kerja yaitu : faktor ekternal, faktor internal, faktor kesempatan kerja dan faktor pemenuhan kebutuhan ekonomi yang menghantar perempuan untuk bekerja di sektor publik.

Tujuan penelitian : 1) Untuk menegtahui keadaan umum perempuan penjual ikan keliling di Kelurahan Tumumpa Dua Kecamatan Tuminting Kota Manado dan 2) Untuk mendeskripsikan bagaimana bentuk peran perempuan penjual ikan keliling dalam meningkatkan pendapatan. Metode penelitian menggunakan metode deskriptif dengan dasar penelitian studi kasus dengan metode pengambilan data menggunakan metode purposive sampling.

Hasil penelitian menunjukan bahwa peran perempuan penjual ikan keliling dalam keluarga sangatlah penting. Meskipun waktu yang digunakan untuk melakukan kegiatan penjualan ikan hanya 2 jam - 3 jam tapi sangat berpengaruh dalam meningkatkan pendapatan keluarga.

Kata kunci : Peran, perempuan penjual ikan keliling, pendapatan
\end{abstract}

\section{PENDAHULUAN}

$$
\text { Sumberdaya }
$$

Indonesia yang melimpah belum diimbangi oleh kualitas sumberdaya manusia pesisir dan sarana penunjang pesisir lainnya, hal ini membuat masyarakat nelayan masih menjadi masyarakat golongan ekonomi rendah. Satria (2009), menyatakan bahwa kemiskinan masyarakat pesisir dapat dibagi tiga macam, yaitu kemiskinan struktural, kemiskinan kultural, dan kemiskinan alamiah. Kusnadi (2003), menambahkan bahwa kemiskinan yang melekat pada masyarakat pesisir itu disebabkan oleh struktur yang tidak mendukung peningkatan kesejahteraan masyarakat serta budaya yang masih melekat dalam masyarakat tersebut. Tingkat sosial ekonomi dan kesejahteraan hidup yang rendah masyarakat nelayan, menyebabkan nelayan menjadi lapisan sosial yang paling miskin. Nurhayati (2007), juga menyatakan bahwa yang mempengaruhi kemiskinan dalam rumah tangga adalah pendapatan dan pendidikan, sedangkan yang mempengaruhi pendapatan adalah tenaga kerja dan investasi, hal ini menunjukan betapa erat kaitannya 
antara kondisi kemiskinan rumah tangga dengan anggota rumah tangga yang bekerja di tingkat pendidikan dan anggota rumah tangga. Ketidakpastian pendapatan yang diperoleh oleh kepala keluarga mendorong anggota rumah tangga lainnya seperti istri dan anak untuk bekerja sehingga dapat memenuhi kebutuhan hidup rumah tangga. Istri nelayan memiliki peran penting dalam peningkatan pendapatan keluarga.

Munawaroh (2008), menyatakan bahwa perempuan adalah sebagai unsur penting dalam keluarga karena mempunyai partisipasi inti sebagai istri, ibu, kawan, pendidik, manager rumah tangga dan majikan. Ada beberapa pokok yang melatarbelakangi keterlibatan perempuan dalam peran kerja. Pertama, keharusan sebagai refleksi dari kondisi ekonomi rumah tangga yang bersangkutan rendah sehingga bekerja untuk meningkatkan pendapatan rumah tangga merupakan satu hal yang penting. Kedua, memilih untuk bekerja sebagai refleksi dari kondisi sosial ekonomi pada tingkat menengah keatas. Ketiga, adalah kondisi dimana perempuan itu berada dalam satu lingkungan tertentu karena faktor budaya masyarakat yang memiliki nilai terhadap pekerjaan tertentu (Anwar, 2007). Perempuan bekerja adalah untuk membantu ekonomi keluarga dan menambah pendapatan untuk mewujudkan kesejahteraan keluarga. Peran perempuan dalam rumah tangga dinilai sangat strategis untuk mengetahui kontribusi perempuan terhadap peningkatan pendapatan rumah tangga yang pada akhirnya dapat dijadikan sebuah solusi untuk meningkatkan kesejateraan rumah tangga yang selama ini identik dengan kemiskinan (Handayani dan Artini, 2009)
Tujuan penelitian ini, yaitu 1) mengetahui keadaan umum perempuan penjual ikan keliling di Kelurahan Tumumpa Dua, KecamatanTuminting, Kota Manado, dan 2) mendeskripsikan bagaimana bentuk peran perempuan penjual ikan keliling dalam meningkatkan pendapatan keluarga.

Lokasi penelitian bertempat di Kelurahan Tumumpa Dua Kecamatan Tuminting Kota Manado dan waktu yang diperlukan untuk melaksanakan penelitian ini mulai dari menyusun rencana kerja penelitian sampai dengan pelaksanaan ujian, selama 4 bulan, yaitu dari bulan September sampai bulan Desember 2017.

\section{METODE PENELITIAN}

Metode penelitian menggunakan metode deskriptif dengan dasar penelitian studi kasus. Metode deskriptif merupakan metode yang digunakan untuk mejelaskan atau menerangkan suatu peristiwa yang terjadi pada saat sekarang. Demikian halnya dengan Arikunto (2006), yang mengatakan apabila penelitian bermaksud mengatahui keadaan sesuatu mengenai apa dan bagaimana, berapa banyak, sejauh mana, maka penelitian deskriptif yaitu mejelaskan atau menerangkan peristiwa.

Studi kasus adalah penelitian terinci tentang seseorang (Individu) atau suatu unit sosial selama kurun waktu tertentu (Aziz, 2003). Lebih tegas menambahkan bahwa penelitian studi kasus adalah penelitian terhadap fenomena dalam konteks kehidupan nyata, bila batas-batas anatara fenomena dan kontekstak tampak dengan tegas dan dimana multi sumber bukti dimanfaatkan. Creswell (2010), mengatakan bahwa studi kasus merupakan strategi penelitian dimana 
didalamnya peneliti menyelidiki secara cermat suatu program, peristiwa, aktivitas, proses atau sekelompok individu.

Metode pengambilan data yang akan digunakan dalam penelitian ini adalah metode purposive sampling. Purposive Sampling adalah teknik sampling yang dilakukan dengan pertimbangan tertentu yang bertujuan agar data yang diperoleh bersifat representatif (Sugiono, 2008). Metode ini dipilih karena melihat dalam penelitian diperoleh 50 orang perempuan penjual ikan, maka sesuai dengan metode yang digunakan maka diambil 30 orang $(60 \%)$ sebagai sampel.

\section{HASIL DAN PEMBAHASAN}

\section{Pengalaman Kerja}

Pengalaman kerja dari perempuan penjaul ikan keliling memiliki jenjang waktu yang berbeda-beda karena ada perempuan penjual ikan keliling yang sudah memiliki pengalaman kerja yang sudah lama dan ada juga yang memiliki pengalaman kerja yang belum lama. Pengalaman kerja perempuan penjual ikan keliling dapat dilihat pada pada tabel 1 .

Tabel 1. Pengalaman Kerja Perempuan Penjual Ikan Keliling

\begin{tabular}{|c|c|c|}
\hline $\begin{array}{c}\text { Lama } \\
\text { Kerja } \\
\text { (Tahun) }\end{array}$ & $\begin{array}{c}\text { JumlahResponden } \\
\text { (orang) }\end{array}$ & Prosentase(\%) \\
\hline $1-5$ & 11 & 36,67 \\
\hline $6-10$ & 12 & 40,00 \\
\hline $11-15$ & 3 & 10,00 \\
\hline $16-20$ & 2 & 6,67 \\
\hline $21-25$ & 2 & 6,66 \\
\hline Total & 30 & 100,00 \\
\hline
\end{tabular}

Sumber : Data Primer,diolah, 2017.

Dapat kita ketahui $36,67 \%$ memiliki pengalaman kerja 1 tahun - 5 tahun, selanjutnya $40,00 \%$ memiliki pengalaman kerja 6 tahun - 10 tahun, $10,00 \%$ memiliki pengalaman kerja 11 tahun - 15 tahun, sedangkan ada 6,67\% yang memiliki pengalaman kerja 16 tahun - 20 tahun.

Pengalaman kerja yang dimiliki oleh perempuan penjual ikan keliling, sehingga proses penjualan ikan bukan hanya terbatas di Kelurahan Tumumpa Dua saja, tapi ada juga di daerah-daerah tertentu yaitu seperti di Pandu, di Sospol, di kompleks Mahawu, di Molas, di kompleks Maasing dan Bailang.

Pengalaman kerja perempuan penjual ikan keliling sangat berpengaruh pada pendapatan karena apabila sudah memiliki pengalaman kerja, dapat mengetahui dimana saja tempat yang memiliki banyak konsumen untuk berjualan ikan. Perempuan penjual ikan keliling dalam melakukan penjualan ikan mereka berjualan pada pagi hari dan hanya sebagian yang melakukan aktivitas berjualan ikan hingga pada sore hari. Melalui pengalaman kerja yang ada perempuan penjual ikan keliling dapat dengan mudah menjual ikan di tempattempat seperti di Molas, di Kompleks Mahawu dan Bailang karena selain tempatnya tidak jauh perempuanperempuan penjual ikan sudah mengetahui jumlah konsumen yang akan membeli ikan jualan mereka.

Perempuan penjual ikan keliling yang memiliki pengalaman kerja diatas 5 tahun, mereka sudah terbiasa dengan aktivitas sehari-hari yaitu berjualan ikan. Sedangkan mereka yang memiliki pengalaman kerja diatas 10 tahun mereka sudah bisa mengetahui tempat mana yang memiliki konsumen yang sering membeli ikan yang dijual bahkan ada yang sudah menjadi langganan para warga setempat.

Sebelum melakukan aktivitas berjualan ikan mereka harus mengerjakan pekerjaan rumah serta kegiatan lainnya, karena pengalaman 
kerja yang dimiliki oleh perempuan penjual ikan keliling, sehingga dituntut untuk bisa mengurus rumah tangga dan melakukan penjualan ikan. Perempuan penjual ikan keliling setiap pagi sudah bangun untuk menyiapkan sarapan untuk seluruh anggota keluarga sesudah itu harus juga berjualan ikan.

\section{Motivasi Kerja}

Perempuan bekerja untuk memenuhi kebutuhan fisiologis yaitu untuk kelangsungan hidupnya. Kebutuhan fisiologi ini terpenuhi barulah perempuan bisa memenuhi kebutuhan hidup lainya seperti aktualisasi diri. Menurut Syahfitriani (2007) ada dua alasan yang merupkan motivasi perempuan untuk bekerja adalah dikarenakan kebutuhan ekonomi dan keinginan aktualisasi diri. Lebih lanjut menjelaskan faktor pertama yang mendorong perempuan bekerja adalah kebutuhan ekonomi. Pendapatan tunggal tidak dapat lagi cukup untuk menghidupi sebuah keluarga, sedangkan faktor kedua adalah untuk aktualisasi diri.

Motivasi kerja adalah daya penggerak yang menciptakan kegairahan kerja seseorang, agar mereka mau bekerja sama, efektif dan terintegrasi dengan segala daya upayanya untuk mencapai kepuasan. Motivasi sebagai proses yang menjelaskan intensitas, arah dan ketekunan usaha untuk mencapai suatu tujuan. Maka dari defenisi tersebut, terlihat jelas bahwa motivasi kerja menjadi salah satu faktor penting yang mempengaruhi perempuan penjual ikan keliling.

Motivasi dalam diri perempuan penjual ikan keliling yaitu adanya dorongan dari dalam diri untuk mau melakukan suatu tugas atau pekerjaan. Motivasi dari responden yang diwawancarai sebagian besar adalah untuk pemenuhan kebutuhan keluarga dan ada juga yang mengatakan untuk mendapat keuntungan dari hasil berjualan ikan. Motivasi dari luar diri yaitu untuk mengaktualisasikan diri dan untuk mencari pengalaman. Motivasi yang lain juga karena faktor suami sebagai nelayan, karena apabila ikan hasil tangkapan tidak dijual oleh istri nelayan tersebut maka jumlah pendapatan akan berkurang. Tapi jika dijual oleh istri nelayan maka jumlah pendapatan lebih banyak dan bisa mencukupi kebutuhan keluarga.

Perempuan penjual ikan keliling yang menjadi responden mempunyai motivasi untuk memenuhi kebutuhan keluarga, membantu suami, untuk mendapatkan keuntungan, sebagai hobi, ada juga yang mengatakan sebagai kebiasaan dari orangtua dan juga sebagai tulang punggung keluarga.

\section{Ukuran Keluarga Perempuan Penjual Ikan Keliling}

Ukuran keluarga perlu diperhatikan, karena jumlah tanggungan keluarga sangat mempengaruhi tingkat kesejahteraan kehidupan. Apabila jumlah tanggungan keluarga sedikit, maka jumlah pendapatan dapat mencukupi kebutuhan keluarga. Sebaliknya, ketika jumlah tanggungan keluarga yang banyak, maka dapat dipastikan bahwa pendapatan tidak dapat mencukupi kebutuhan keluarga sehari-hari. Jumlah tanggungan keluarga dapat dilihat pada tabel 2 .

Tabel 2. Ukuran Keluarga Perempuan Penjual Ikan

\begin{tabular}{|c|c|c|c|}
\multicolumn{4}{c|}{ Keliling } \\
No. & $\begin{array}{c}\text { Jumlah } \\
\text { Anggota } \\
\text { Keluarga } \\
\text { (Orang) }\end{array}$ & $\begin{array}{c}\text { Jumlah } \\
\text { Responden } \\
\text { (Orang) }\end{array}$ & $\begin{array}{c}\text { Prosentase } \\
(\%)\end{array}$ \\
\hline 1. & 3 & 7 & 23,33 \\
\hline 2. & 4 & 11 & 36,67 \\
\hline
\end{tabular}




\begin{tabular}{|l|c|c|c|}
\hline 3. & 5 & 9 & 30,00 \\
\hline 4. & Lebih dari 5 & 3 & 10,00 \\
\hline \multicolumn{2}{|c|}{ Jumlah total } & 30 & 100,00 \\
\hline
\end{tabular}

Sumber : Data Primer,diolah, 2017.

Sebanyak $36,7 \%$ pada penelitian ini memiliki tanggungan keluarga sebanyak empat orang yaitu suami, istri dan dua anak. Sedangkan ada 10,00\% memiliki jumlah tanggungan terbanyak yaitu lebih dari 5 orang. Kebutuhan yang ditanggung oleh perempuan penjual ikan keliling yaitu sandang, pangan dan papan. Sandang adalah pakaian yang dibutuhkan oleh manusia sebagai makluk yang berbudaya. Pangan adalah kebutuhan yang sangat penting bagi tubuh manusia yaitu makanan dan minuman. Papan adalah kebutuhan manusia untuk tempat tinggal atau rumah. Tanggungan keluarga perempuan responden selain kebutuhan untuk makan serta tempat tinggal, kebutuhan lain adalah untuk biaya sekolah anak, yakni untuk pembayaran sekolah dan juga kebutuhan sekolah seperti alat tulis.

Jumlah tanggungan keluarga dari perempuan penjual ikan keliling ada $36,67 \%$ yaitu memiliki tanggungan 4 orang. Jumlah tanggungan 4 orang dari hasil wawancara langsung dengan perempuan penjual ikan keliling seringkali tidak dapat mencukupi pendapatan keluarga. Begitupun sebaliknya apabila jumlah tanggungan keluarga kurang dari 4 orang maka akan dapat mencukupi pendapatan.

\section{Jumlah Pendapatan Suami Perempuan Penjual Ikan Keliling}

Jumlah pendapatan suami digunakan untuk mencukupi setiap kebutuhan keluarga. Jumlah pendapatan suami seringkali tidak dapat mencukupi kabutuhan keluarga sehingga mengharuskan para perempuan untuk bekerja membantu suami. Tabel 3 dapat menjelaskan pendapatan suami perempuan penjual ikan keliling.

Tabel 3. Jumlah Pendapatan Suami Responden

\begin{tabular}{|c|c|c|c|}
\hline No. & $\begin{array}{c}\text { Jumlah } \\
\text { Pendapatan } \\
\text { Suami } \\
\text { Responden (Rp) }\end{array}$ & $\begin{array}{c}\text { Jumlah } \\
\text { Responden } \\
\text { (Orang) }\end{array}$ & $\begin{array}{c}\text { Prosentase } \\
(\%)\end{array}$ \\
\hline 1. & Tidak ada & 2 & 6,67 \\
\hline 2. & $\begin{array}{l}800.000- \\
1.000 .000\end{array}$ & 21 & 70,00 \\
\hline 3. & $\begin{array}{c}1.100 .000- \\
2.000 .000\end{array}$ & 4 & 13,33 \\
\hline 4. & $\begin{array}{c}2.100 .000- \\
3.000 .000\end{array}$ & 3 & 10,00 \\
\hline & Jumlah & 30 & 100,00 \\
\hline
\end{tabular}

Sumber : Data Primer, diolah, 2017.

Sebanyak 70,00\% perempuan penjual ikan memiliki penghasilan suami Rp. 800.000 - Rp. 1.000.000, ada $13,33 \%$ dengan pendapatan Rp. 1.000 .000 - Rp. 2. 000.000 , ada $10,00 \%$ dengan pendapatan Rp. $2.100 .000-R p$. 3.000.000, sedangkan untuk jumlah paling sedikit yaitu ada $6,67 \%$ tidak memiliki penghasilan suami. Melihat tingkat pendapatan yang ada maka tidak bisa mencukupi kebutuhan keluarga dalam satu bulan.

Sebagian besar suami dari responden memiliki penghasilan $\mathrm{Rp}$. 800.000 - Rp. 1.000.000, dari penghasilan yang diperoleh belum bisa memenuhi kebutuhan keluarga maka perempuan responden harus berperan aktif juga dalam memenuhi kebutuhan keluarga.

Suami perempuan penjual ikan keliling memiliki pekerjaan yang berbeda beda dari hasil wawancara pekerjaan dari suami perempuan penjual ikan keliling adalah nelayan, tukang, buruh dan juga pekerja tambang. Tapi ada juga yang belum memiliki pekerjaan atau tidak bekerja, jadi perempuan penjual ikan bekerja untuk memenuhi kebutuhan keluarga. Pekerjaan dari perempuan 
penjual ikan keliling dapat dilihat pada tabel 4.

Tabel 4. Pekerjaan Suami Perempuan Penjual Ikan Keliling

\begin{tabular}{|c|l|c|c|}
\hline No. & JenisPekerjaan & $\begin{array}{c}\text { Jumlah } \\
\text { Responden } \\
\text { (Orang) }\end{array}$ & $\begin{array}{c}\text { Prosentase } \\
(\%)\end{array}$ \\
\hline 1. & Tidak ada & 2 & 6,67 \\
\hline 2. & Nelayan & 19 & 63,33 \\
\hline 3. & Tukang & 4 & 13,33 \\
\hline 4. & Buruh & 3 & 10,00 \\
\hline 5. & $\begin{array}{l}\text { Pekerja } \\
\text { Tambang }\end{array}$ & 2 & 6,66 \\
\hline & Jumlah & 30 & 100,00 \\
\hline
\end{tabular}

Sumber : Data Primer, diolah, 2017.

$$
\text { Sebanyak 63,33\% bekerja }
$$

sebagai nelayan, $13,33 \%$ sebagai tukang, 10\% sebagai buruh, 6,66 pekerja tambang dan 6,67 tidak memiliki pekerjaan. Jumlah pendapatan sebagai nelayan antara Rp. 1.000 .000 - Rp. 3.000 .000 setiap bulannya, untuk tukang antara Rp. 800.000 - Rp. 1.200 .000 setiap bulannya.

\section{Jumlah Pendapatan Perempuan Penjual Ikan Keliling}

Menurut Eryanto (2013), pendapatan adalah seluruh penerimaan baik berupa uang ataupun barang dari pihak lain maupun dari pihak sendiri. Pendapatan dapat diartikan sebagai sesuatu yang diperoleh melalui usaha yang dinyatakan dalam rupiah. Berdasarkan hasil penelitian kepada perempuan penjual keliling jumlah pendapatan dalam sehari berkisar Rp. 50.000 - Rp. 100.000/orang, tapi ada juga yang memiliki pendapatan lebih dari Rp. 100.000/harinya. Jumlah pendapatan dari perempuan dapat dilihat pada tabel 5 .

Tabel 5. Jumlah Pendapatan Perempuan Penjual Ikan Keliling

\begin{tabular}{|c|c|c|c|}
\hline No. & $\begin{array}{c}\text { Jumlah } \\
\text { Pendapatan } \\
(\mathrm{Rp})\end{array}$ & $\begin{array}{c}\text { Jumlah } \\
\text { Responden } \\
\text { (Orang) }\end{array}$ & $\begin{array}{c}\text { Prosentase } \\
(\%)\end{array}$ \\
\hline 1. & $\begin{array}{c}1.000 .000- \\
2.000 .000\end{array}$ & 15 & 50,00 \\
\hline 2. & $2.100 .000-$ & 6 & 20,00 \\
\hline
\end{tabular}

\begin{tabular}{|c|c|c|c|}
\hline & 3.000 .000 & & \\
\hline 3. & $\begin{array}{c}3.100 .000- \\
4.000 .000\end{array}$ & 4 & 13,33 \\
& $4.100 .000-$ & 5 & 16,67 \\
\hline 4. & 5.000 .000 & & \\
\hline \multicolumn{2}{|c|}{ Jumlah Total } & 30 & 100,00 \\
\hline
\end{tabular}

Sumber : Data Primer, Diolah, 2017.

Hasil ini menunjukkan bahwa sebagian besar perempuan responden memiliki pendapatan Rp1.000.000 - Rp. 2.000 .000 yaitu ada $50,00 \%$, dengan pendapatan Rp. 2.000 .000 - Rp. 3.000 .000 ada $20,00 \%$, dengan pendapatan Rp. 3.100 .000 - Rp. 4.000 .000 ada $13,33 \%$, sedangkan dengan pendapatan Rp. 4.100.000 - Rp. 5.000 .000 ada $16,67 \%$ jumlah pendapatan dalam satu bulan.

Jumlah pendapatan tinggi perempuan penjual ikan keliling dapat mencapai kurang lebih Rp. 5.000.000 per bulan, dengan pendapatan tersebut masih kurang untuk mencukupi kebutuhan keluarga dalam satu bulan, apalagi jika dalam keluarga tersebut hanya berharap kepada perempuan dan laki-laki tidak ada pekerjaan. Maka dalam memenuhi kebutuhan keluarga perempuan dituntut untuk ikut serta dalam memenuhi kebutuhan keluarga.

Peran perempuan penjual ikan keliling dalam meningkatkan pendapatan keluarga yaitu ada juga perempuan yang berjualan kue, dan buka usaha warung. Perempuan yang berjualan kue dalam seharinya bisa mendapatkan untung Rp. 150.000, sedangkan untuk yang buka usaha warung seringkali pendapatanya tidak menentu karena adanya persaingan, serta ada masyarakat yang sudah membali setiap bahan-bahan makanan di supermarket atau pasar tradisional.

\section{Tingkat Pengeluaran Keluarga Perempuan Penjual Ikan Keliling} Pengeluaran dalam rumah tangga yaitu kebutuhan sehari-hari 
seperti makan, kebutuhan sekolah, pembayaran listrik lampu dan juga kebutuhan suami untuk melaut bagi perempuan nelayan. Kebutuhan akan makananlah yang sangat banyak karena tergantung jumlah tanggungan keluarga, apabila jumlah tanggungan keluarga kurang dari 5 orang maka tingkat pengeluaran pun sedikit serta dapat tercukupi. Kebutuhan tetap adalah kebutuhan yang harus dipenuhi dalam satu bulan dan memiliki uang yang jelas. Sedangkan kebutuhan tidak tetap adalah kebutuhan yang harus dipenuhi, tetapi tidak memiliki uang yang jelas karena kebutuhannya tidak menentu. Tingkat pengeluaran dapat dilihat pada tabel 6 .

Tabel 6. Tingkat Pengeluaran Keluarga Perempuan Penjual Ikan Keliling

\begin{tabular}{|c|c|c|c|}
\hline No. & $\begin{array}{c}\text { Jumlah } \\
\text { Pengeluaran } \\
(\mathrm{Rp})\end{array}$ & $\begin{array}{c}\text { Jumlah } \\
\text { Responden } \\
\text { (orang) }\end{array}$ & $\begin{array}{c}\text { Prosentase } \\
(\%)\end{array}$ \\
\hline 1. & $\begin{array}{c}1.000 .000- \\
2.000 .000\end{array}$ & 8 & 26,67 \\
\hline 2. & $\begin{array}{c}2.100 .000- \\
3.000 .000\end{array}$ & 10 & 33,33 \\
\hline 3. & $\begin{array}{c}3.100 .000- \\
4.000 .000\end{array}$ & 10 & 33,33 \\
\hline 4. & $\begin{array}{c}4.100 .000- \\
5.000 .000\end{array}$ & 2 & 6,67 \\
\hline \multicolumn{2}{|c|}{ Jumlah Total } & 30 & 100,00 \\
\hline
\end{tabular}

Sumber : Data Primer, diolah, 2017.

Tingkat pengeluaran keluarga perempuan penjual ikan keliling ada $26,67 \%$ dengan pengeluaran $\mathrm{Rp}$. 1.000 .000 - Rp. 2.000 .000 , ada 33,33\% dengan pengeluaran Rp. 2.100 .000 Rp. 3.000 .000 , ada $33,33 \%$ dengan pengeluaran Rp. 3.100 .000 - Rp. 4.000.000, sedangkan $6,67 \%$ dengan pengeluaran Rp. 4.100 .000 - Rp. 5.000 .000 dalam satu bulan. Pengeluaran dalam keluarga untuk perempuan penjual ikan keliling ada 33\% dengan jumlah pengeluaran $\mathrm{Rp}$. 2.100.000 - Rp. 3.000.000 per bulan. Sedangkan ada $6,67 \%$ dengan jumlah pengeluran Rp. 4.100 .000 - Rp. 5.000 .000 per bulan.
Pengeluran dari perempuan penjual ikan keliling, yaitu makanan, perumahan, sekolah anak dan juga pakaian. Tingkat pengeluaran untuk makanan dari 30 responden semua memiliki tingkat pengeluaran seperti makanan dengan jumlah pengeluaran Rp. 1.500 .000 - Rp. 4.500 .000 setiap bulan, untuk pakaian ada 18 responden dengan pengeluaran Rp. $100.000-\mathrm{Rp}$. 300.000 setiap bulan, untuk perumahan dari 30 responden ada semua memiliki pengeluran untuk rumah Rp. 50.000 Rp. 200.000 setiap bulan, biaya sekolah anak dari 30 responden ada 24 responden yang memiliki tanggungan biaya sekolah dengan pengeluaran Rp. 50.000 - Rp. 500.000 setiap bulan.

\section{Deskripsi Antar Variabel Keadaan Umum Responden}

Umur memiliki pengaruh sangat besar terhadap kehidupan manusia, umur perempuan penjual ikan keliling tergolong usia produktif yaitu dari 15 tahun - 45 tahun sehingga mereka dapat berkarya dan melakukan setiap pekerjaan dengan baik. Umur tidak dapat mempengaruhi sesorang untuk memiliki pendidikan karena dari hasil wawancara terhadap perempuan penjual ikan keliling, ada perempuan yang masih muda atau berusia 25 tahun - 30 tahun lulusan Sekolah Dasar, dan ada yang berusia 40 tahun - 50 tahun yang Iulusan Sekolah Dasar. Umur terhadap pengalaman kerja perempuan penjual ikan kelilling yaitu semakin lama atau semakin tinggi umur maka pengalaman kerja pun semakin banyak. Perempuan penjual ikan keliling sebagian besar memiliki pengalaman kerja 6 tahun ke atas. Umur terhadap motivasi kerja dari perempuan penjual ikan keliling diketahui dari hasil wawancara walaupun usia masih muda atau tua memiliki 
motivasi kerja yaitu untuk memenuhi kebutuhan keluarga, mengaktualisasikan diri dan untuk mencari pengalaman. Perempuan yang berusia 30 tahun - 45 tahun mereka lebih aktif karena dalam satu hari bisa sampai dua kali melakukan aktivitas berjualan ikan yaitu pagi dan sore, serta bisa mengatur setiap kegiatan dalam rumah tangga baik kegiatan mengurus rumah tangga dan kegiatan untuk memenuhi kebutuhan keluarga, berbeda dengan yang berusia non produktif yaitu usia 50 tahun - 60 tahun dan usia 0 tahun - 14 tahun.

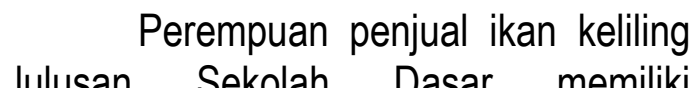
pengalaman kerja lebih banyak karena masa muda sudah digunakan untuk menjual ikan. Berbeda dengan perempuan penjual ikan yang melanjutkan sekolah di jenjang yang lebih tinggi mempunyai pengalaman kerja yang lebih singkat. Pendidikan terhadap motivasi kerja perempuan penjual ikan keliling adalah ada yang memiliki motivasi kerja karena ingin mendapatkan keuntungan dari hasil penjualan sehingga keuntungan itu dapat digunakan untuk menambah pemenuhan kebutuhan rumah tangga.

Pengalaman kerja yang semakin lama maka mejadikan seseorang memiliki motivasi kerja yang berbeda pula, dari 30 responden perempuan penjual ikan keliling di Kelurahan Tumumpa Dua memiliki pengalaman kerja di atas 6 tahun. Pengalaman kerja yang ada menjadi motivasi bagi perempuan untuk tetap melakukan aktivitas berjualan ikan, walaupun sudah banyak cara yang dapat dilakukan untuk bisa mendapatkan ikan, yaitu bisa ke supermarket dan ke pasar tradisional. Pengalaman kerja dari perempuan tetap terus memotivasi untuk tetap berjualan ikan, karena untuk pemenuhan kebutuhan keluarga bahkan sudah menjadi hobi.

Pendapatan yang diperoleh sangat berpengaruh terhadap curahan waktu yang digunakan dalam suatu pekerjaan, seperti halnya curahan waktu dari perempuan penjual ikan keliling dalam mencukupi kebutuhan keluarga. Curahan waktu dari perempuan penjual ikan keliling dalam satu hari 2 jam - 3 jam yaitu para istri nelayan yang hanya menggunakan waktu senggang untuk berjualan karena suami adalah nelayan, tapi perempuan yang memiliki waktu 5 jam - 6 jam adalah mereka yang menggunakan setengah dari aktivitas mereka dalam satu hari untuk menjual ikan. Maka dari waktu yang mereka gunakan otomatis lebih banyak pendapatan adalah perempuan yang menggunakan waktu 5 jam - 6 jam dalam satu hari.

\section{Peran Perempuan dalam Keluarga}

Peran Perempuan dalam keluarga sangatlah penting karena melihat tugas yang harus dilaksanakan mulai dari pagi sampai malam tak lepas dari tanggung jawab yang tidak bisa dihindari. Pengaturan atau pengelolaan rumah tangga yang tidak mengenal waktu tersebut berkaitan dengan mengasuh, mendidik, menjaga dan menggarahkan anak-anak terutama bagi yang belum dewasa. Mengurus, membersikan, membereskan rumah termasuk perabot rumah dan menjaga kebersihan serta kerapian pakaian seluruh anggota keluarga.

Waktu yang diperlukan dalam kegiatan domestik adalah lebih dari 10 jam, dengan waktu tersebut dapat melakukan aktivitas seperti memasak, mencuci, mengurus anak dan mengurus rumah tangga. Perempuan harus belajar 
untuk dapat menyelesaikan setiap pekerjaan dengan cepat, walaupun seringkali mengorbankan kegiatan publik untuk dapat menyelesaiakan kegiatan domestik yaitu mengurus rumah tangga.

Perempuan juga merupakan penggerak dalam keluarga, karena tanpa perempuan akan susah menangani masalah kebutuhan dalam keluarga. Tanggung jawab besar yang membutuhkan kesabaran sehingga menjadi pribadi yang dapat diandalkan. Tugas tersebut membuat perempuan harus bisa memanajemen waktu dengan baik.

Peran perempuan dalam keluarga seperti pada tabel di atas dari 30 responden ada 28 responden yang melakukan aktivitas memasak, 2 responden yang tidak melakukan aktivitas memasak karena sudah dilakukan oleh anggota keluarga lain seperti saudara dan juga orang tua (ibu). Membersihkan baju atau mencuci baju dan membersihkan perabot rumah tangga dari hasil wawancara 30 responden melakukan aktivitas tersebut, sedangkan untuk mengurus anak hanya 8 responden karena 22 responden sudah tidak memiliki anak balita. Peran perempuan dalam keluarga sangatlah penting karena sebagian besar aktivitas di rumah dilakukan oleh perempuan yaitu untuk mengurus anak, mengurus rumah tangga dan untuk memenuhi kebutuhan keluarga seperti menjual ikan.

\section{Peran Perempuan dalam Organisasi Sosial}

Perempuan penjual ikan keliling
selain melaksanakan tugas rumah
tangga dan membantu suami dalam
memenuhi kabutuhan, perempuan yang
menjadi responden juga tetap aktif dalam kegiatan kemasyarakatan seperti arisan dan juga PKK. Peran perempuan dalam organisasi sosial seperti PKK melatih perempuan untuk dapat menambah penghasilan suami dalam berbagai ketrampilan. Ketrampilanketrampilan tersebut adalah membuat kue, mengolah ikan hasil tangkapan, dan juga pembuat kerajinan menggunakan barang-barang bekas.

Ada $20,00 \%$ yang mengikuti organisasi arisan, ada $33,33 \%$ yang mengikuti organisasi PKK, kegiatan pengajian ada $30,00 \%$, kegiatan rukun keluarga ada 30,00\%, kegiatan kaum ibu ada $20,00 \%$, sedangkan untuk organisasi duka semua responden turut ambil bagian.

Kegiatan arisan yang diikuti oleh perempuan penjual ikan keliling biasanya diadakan satu minggu satu kali yaitu pada hari selasa. Apa yang dilakukan oleh ibu-ibu atau perempuanperempuan ini adalah setiap kali pertemuan mereka sudah membuat kesepakatan untuk mengumpulkan uang setiap anggota Rp. 10.000, seusai pengumpuan uang mereka akan melakukan pemilihan siapa yang akan uang yang sudah dikumpulkan, serta kegiatan ini dilakukan secara bergantian. Ada 20\% perempuan penjual ikan keliling yang mengikuti kegiatan arisan.

Kegiatan PKK ada 33,33\% perempuan penjual ikan keliling yang mengikuti kegiatan tersebut. Kegaitan PKK lebih aktif pada saat kegiatan HUT RI karena para ibu-ibu ikut ambil bagian dalam lomba yang diadakan seperti lomba membuat kue dan lomba merangkai bunga. Kegiatan PKK dilakukan satu minggu satu kali pertemuan.

Kaum ibu yaitu yang hadir hanya ibu-ibu dan hanya untuk ibu-ibu yang beragama Kristen Protestan. Kaum ibu 
dilakukan satu minggu satu kali setiap hari jumat. Ada 20,00\% perempuan yang ikut ambil bagian dalam kegiatan kaum ibu, dari wawancara dengan perempuan penjual ikan keliling mengatakan bahwa kegiatan kaum ibu dilakukan untuk menjalin persekutuan dengan sesama, serta bentuknya yaitu ibadah bersama. Selain untuk menjalin hubungan dengan sesama kaum ibu ini dilakukan untuk melatih setiap ibu-ibu untuk bisa mengaktualisasikan diri mereka.

Ada $\quad 100,00 \%$ atau 30 perempuan penjual ikan keliling yang mengikuti kegiatan duka karena sudah menjadi budaya masyarakat khususnya Sulawesi Utara, karena apabila ada kedukaan semua pihak ikut terlibat baik untuk persiapan ibadah dan untuk ambil bagian membantu keluarga yang berduka.

Pengajian hanya dilakukan oleh $30,00 \%$ perempuan penjual ikan keliling, karena ada juga perempuan yang tidak mengikuti kegiatan pengajian. Pengajian Tabel 7. Alokasi waktu kerja

\begin{tabular}{|c|c|c|c|c|}
\hline \multirow{2}{*}{$\begin{array}{c}\text { JumlahResponden } \\
\text { (Orang) }\end{array}$} & \multicolumn{4}{|c|}{ CurahanWaktuKerja } \\
\cline { 2 - 5 } & $\begin{array}{c}\text { Curahan waktu kerja } \\
\text { di Rumah (Jam) }\end{array}$ & $\begin{array}{c}\text { Curahan Waktu Kerja } \\
\text { Menjual Ikan (Jam) }\end{array}$ & $\begin{array}{c}\text { Presentase Waktu di } \\
\text { Rumah (\%) }\end{array}$ & $\begin{array}{c}\text { Presentase Waktu } \\
\text { Menjual Ikan (\%) }\end{array}$ \\
\hline 16 & $8-9$ & $3-4$ & 75 & 25 \\
\hline 9 & $6-7$ & $5-6$ & 58 & 42 \\
\hline 5 & $6>$ & $6>$ & 50 & 50 \\
\hline
\end{tabular}

Sumber : Data Primer, 2017.

Alokasi waktu kerja 8 jam - 9 jam di rumah dengan presentase $75 \%$ dan alokasi waktu kerja menjual ikan 3 jam 4 jam dengan presentase $25 \%$. Selanjutnya ada 9 responden yang memiliki alokasi waktu kerja 6 jam - 7 jam dengan presentase $58 \%$ dan alokasi waktu berjualan ikan $42 \%$. Sedangkan 5 responden memiliki waktu kerja lebih dari 6 jam untuk berjualan dan melakukan aktivitas dirumah dengan presentase $50 \%$. Maka dari tabel 12 juga dapat diketahui bahwa sebagian besar perempuan penjual ikan keliling dilakukan ada yang satu minggu satu kali dan ada juga tiga kali dalam seminggu. Ada juga perempuan yang mengajar anak-anaknya untuk mengaji di rumah.

Rukun keluarga merupakan jalinan kebersamaan antara keluargakeluarga, di Kelurahan Tumumpa ada $30,00 \%$ perempuan yang mengikuti kegiatan rukun keluarga. Biasanya kegiatan rukun keluarga dilakukan 2 minggu satu kali dan dilakukan ditempattempat yang berganti atau bergiliran.

\section{Curahan Waktu Kerja}

Curahan waktu kerja perempuan dapat digolongkan jadi dua yaitu untuk kegiatan ekonomis dan non ekonomis. Curahan waktu kerja adalah lama pekerjaan yang kita lakukan dalam satu hari yang dihitung dengan jam. Curahan waktu kerja perempuan penjual ikan keliling dapat dilihat pada Tabel 7 . menggunakan waktu kerja di rumah lebih banyak dari pada di luar rumah yaitu berjualan ikan. Tapi ada juga yang memiliki waktu berjualan ikan dan waktu di rumah seimbang.

Curahan waktu kerja di Rumah dari perempuan penjual ikan keliling dapat kita lihat bahwa ada 53,33\% perempuan yang menggunakan waktu kerjannya 8 jam - 9 jam di rumah, karena tugas utama perempuan adalah melakukan semua kegiatan rumah tangga mulai dari bangun pagi perempuan sudah harus melakukan 
aktivitas seperti membersihkan rumah, mencuci perabot rumah, mengurus rumah, mengurus anak serta memasak. Ada $30,00 \%$ perempuan yang menggunakan waktu kerjannya 6 jam - 7 jam di rumah, untuk melakukan aktivitas dirumah, dan ada $16,67 \%$ perempuan yang menggunakan waktu kerjannya lebih dari 6 jam dirumah.

Curahan waktu kerja di rumah untuk melakukan pekerjaan rumah dan mengurus rumah tangga merupakan aktivitas yang sudah menjadi tanggung jawab perempuan, begitu pula perempuan penjual ikan keliling yaitu sebagian besar menggunakan waktunya di rumah. Waktu di rumah yaitu untuk mengurus anak, membersihkan perabot rumah, mencuci baju dan juga memasak. Berbeda halnya dengan waktu untuk menjual ikan yaitu 2 jam - 3 jam.

Curahan waktu menjual ikan perempuan penjual ikan keliling ada $16,67 \%$ yang manggunakan waktu kerja berjualan ikan lebih dari 6 jam dalam sehari, ada $30,00 \%$ yang menggunakan waktu kerja berjualan ikan 5 jam - 6 jam dalam sehari, dan ada 53,33\% perempuan yang menggunakan waktu kerja berjualan ikan 3 jam - 6 jam dalam sehari. Meskipun sebagain besar perempuan yang menggunakan waktu kerja untuk berjualan ikan 3 jam - 4 jam, pendapatan dari penjualan ikan dapat menambah pendapatan keluarga untuk memenuhi kebutuhan setiap harinya.

\section{KESIMPULAN DAN SARAN \\ Kesimpulan}

1. Keadaan umum perempuan penjual ikan keliling di Kelurahan Tumumpa Dua ada 30 orang responden yang diteliti berumur 41 tahun - 50 tahun, dengan menempuh pendidikan sebagian besar lulusan Sekolah Dasar. Motivasi yang dimiliki oleh perempuan penjual ikan keliling adalah untuk memenuhi kebutuhan keluarga, dengan pengalaman kerja 6 tahun - 10 tahun. Sedangkan untuk jumlah tanggungan keluarga dalam satu rumah ada 4 orang yaitu suami, istri dan 2 anak.

2. Bentuk peran perempuan penjual ikan keliling yaitu selain mengurus rumah tangga karena merupakan kodrat perempuan, perempuan juga berperan dalam meningkatkan pendapatan keluarga. Bentuk perannya yaitu bisa mengatur waktu antara waktu untuk mengurus rumah tangga dan waktu untuk bekerja memenuhi kebutuhan rumah tangga. Ada $76,67 \%$ perempuan yang yang memiliki peran dalam meningkatkan pendapatan keluarga yaitu menjual ikan keliling karena memiliki pendapatan lebih besar dari suami sehingga menjadi sumber pendapatan keluarga. Kegiatan tambahan lain juga yang dilakukan oleh perempuan selain berjualan ikan untuk meningkatkan pendapatan yaitu dengan menjual kue dan usaha warung meskipun pendapatannya tidak seberapa.

\section{Saran}

Untuk pemerintah setempat agar bisa menyediakan koperasi bagi perempuan penjual ikan keliling untuk menambah modal usahannya.

\section{DAFTAR PUSTAKA}

$$
\begin{array}{crr}
\text { Anwar. 2007.Perubahan Sosial } & \text { Melalui } \\
\text { Pemebelajaran } & \text { Vocational } & \text { Skill } \\
\text { PadaKeluargaNelayan. Alfabeta. Bandung. }
\end{array}
$$


Arikunto. 2006. Prosedur Penelitian: Suatu Pendekatan Praktik. Jakarta: Rineka Cipta.

Aziz,H.A. 2003.Riset Keperawatan dan Tehnik Penulisan IImiah. Jakarta: SalembaMedika.

Badan Pusat Statistik Jakarta Pusat , 2011. Pedoman Pendataan Survei Sosial Ekonomi Nasional Tahun 2011. Jakarta Pusat: Badan Pusat Statistik

Basrowi. 2005. Pengantar Sosiologi, Bogor: Ghalia Indonesia.

Creswell, J. W., 2010. Research design: pendekatan kualitatif, kuantitatif, dan mixed. Yogjakarta: PT Pustaka Pelajar.

Departemen Sosial. 2003. Panduan Umum Studi Kelayakan Persiapan Pemberdayaan.

Eryanto dan Rika. 2013. Pengaruh Modal, Tingkat Pendidikan Orang Tua dan Tingkat Pendapatan Orang Tua Terhadap Prestasi Akademik pada Mahasiswa Fakultas Ekonomi Negri Jakarta. Jurnal Ekonomi Bisnis.

Handayani dan Artini. 2009. Kontribusi Pendapatan Ibu Rumah Tangga Pembuat Makanan Olahan Terhadap Pendapatan Keluarga. Piramida Jurnal Kependudukan dan Pengembangan Sumber Daya Manusia. Volume V No 1 Juni 2009.

Harijani, D. R. 2001. Etos Kerja Perempuan Desa Realisasi Kemandirian dan Produktivitas Ekonomi. Medprint Offset. Yogyakarta.

Hidayat, A.A.A., 2006. Pengantar Kebutuhan Dasar Manusia: Aplikasi Konsep dan Proses Keperawatan. Jakarta. Salemba Medika.

Idrus, M. 2009. Metode Penelitian IImu Sosial. Yogyarkarta: Erlangga.
Kusnadi, 2003. Akar Kemiskinan Nelayan. Yogyakarta: Lkis Pelangi Aksara. $136 \mathrm{hlm}$.

Kusnadi, 2006. Perempuan Pesisir. Yokyakarta : L Kis Yokyakarta.

Mugni, A. 2006. Strategi Rumah Tangga Nelayan dalam Mengatasi Kemiskinan (Studi Kasus Nelayan Desa Limbangan, Kecamatan Juntinyuat, Kabupaten Indramayu.

Munawaroh. 2008. Wanita Tani Nelayan di Kecamatan Kedung. Sinar Harapan. Jepara.

Nurhayati, M., 2007. Analisis Faktor yang mempengaruhi Tingkat Kemiskinan di Jawa Barat. Skripsi. Program Studi IImu Ekonomi. Fakultas Ekonomi dan Manajemen. Institut Pertanian Bogor. IPB.

Reksoprayitno, 2004. Sistem Ekonomi dan Demokrasi Ekonomi. Jakarta : Bina Grafia.

Satria, A. 2009. Ekologi Politik Nelayan, Yogyakarta : LKis Yogyakarta. Hal.188.

Sudarwati, L. 2003. Wanita dan Struktur Sosial (Suatu Analisa Tentang Peran Ganda Wanita Indonesia). Medan. Universitas Sumatera Utara.

Sugiono, 2008. Metode Penelitian Kuantitatif, Kualitatif, dan $R \& D$, Alphabet. Bandung.

Suhendi, Hendi. 2001. Pengantar Studi Sosiologi Keluarga. CV Pustaka Setia. Bandung.

Syarbaini dan Syahrial . 2009. Sosiologi dan Politik. Bogor: Ghalia Indonesia.

Tsalim, A. 2013. Data Kualitatif, Data Kuantitatif, Populasi dan sampel dalam Penelitian.

Wiludjeng, Henny, Attashendartini Habsjah, dan Wibawa. 2005. Dampak Pembakuan Peran Gender terhadap Perempuan Kelas Bawah di Jakarta. Jakarta : LBH-APIK. 